Данко Д.В.

\title{
Геополітичні, демографічні та соціально-економічні характеристики Закарпатської області, як важливі чинники реформи системи охорони здоров'я в регіоні
}

\author{
ДВНЗ «Ужгородський національний університет», м. Ужгород, Україна \\ dankodana01@gmail.com
}

\author{
Данко Д.В. \\ Геополитические, демографические и социально- \\ экономические характеристики Закарпатской области \\ как важные составляющие реформы \\ системы здравоохранения в регионе \\ ГВУЗ «Ужгородский национальный университет», \\ г. Ужгород, Украина
}

\begin{abstract}
Danko D.V.
Geopolitical, demographic and socio-economic characteristics of Transcarpathian region, as important factors of healthcare reform in the region SU "Uzhhorod national university", Uzhhorod, Ukraine
\end{abstract}

\section{Вступ}

В Україні проводиться комплексна реформа охорони здоров'я $[1,2]$. На даному етапі вона визначена впровадженням Закону України від 19 жовтня 2017 року № 2168-VIII «Про державні фінансові гарантії медичного обслуговування населення» [3]. На першому етапі було впроваджено на первинному рівні надання медичної допомоги сімейну медицину [4] з визначенням іiі обсягів [5]. В теперішній час проводиться робота з реформування спеціалізованої та високоспеціалізованої медичної допомоги з фінансуванням визначених медичних послуг за єдиними для країни тарифами [6,7]. Це практично не враховує регіональні геополітичні, медико-демографічні та соціально-економічні особливості.

Мета роботи: дослідити геополітичні, демографічні та соціально-економічні характеристики Закарпатської області в аспекті проведення реформи системи охорони здоров'я в регіоні.

\section{Матеріали та методи}

Матеріалами дослідження стали дані державної та галузевої статистичної звітності за період 20012018 років. Методами дослідження були статистичний та структурно-логічного аналізу.

\section{Результати дослідження та їх обговорення}

Закарпатська область, яка займає територію площею 12,8 тис км ${ }^{2}$ із яких майже $80 \%$ займають гори розташована на крайньому заході країни та має кордони із такими країнами як Польща (протяжність 33,4 км), Словаччиною (98,5 км), Угорщиною (130,0 км), Румунією (205,4 км) та Львівською і Івано-Франківською областями.
На території 13 адміністративних територій, 5 міст обласного значення, 11 міських, 19 селищних та 293 сільських рад області на кінець 2018 року проживало 1254 тис. осіб близько ста національностей із яких $80,5 \% €$ українцями, $12,1 \%$ угорцями, $2,6 \%$ румунами (дані перепису 2001 року).

Водний режим області формує річка Тиса протяжність якої по Україні становить 262 км, а ії наповненість залежить від природно-кліматичних умов i тісно пов'язана із станом Капратських лісів. На території області існують такі природоохороні об'єкти як Карпатський біосферний заповідник та такі національні природні парки: Зачарований край, Ужанський і Синевір.

При цьому Закарпатська область є курортним регіоном європейського рівня 3 наявністю мінеральної та термальної унікальної за своїм хімічним складом води. Розвитку туризму європейського рівня сприяє як наявність умов для рекреації так і наявність 1837 пам'яток історії, культури та архітектури.

Великій кількості людей, які пересуваються по території області сприяє наявність розгалуженої транспортної мережі в тому числі дві дороги державного значення та європейського транспортного коридору №5 Венеція-Трієст/копер-Любляна-Марибор-Будапешт-

Ужгород-Львів-Київ та мережа магістральних транснаціональних газо- та нафтопродуктопроводів.

В економіці Закарпаття основну частину займають такі види господарської діяльності як машинобудування, сількогосподарське виробництво, харчова промисловість, вироблення одягу і виробів із шкіри, лісозаготівля та переробка деревини. При цьому в області налічується понад 280 родовищ мінеральної сировини які включають більше 26 видів корисних копалин.

В області активно розвивається зовнішньоекономічна діяльність, яка в 2018 році налічувала партнерів із 123 країн світу. 
В плані характеристики області, що є важливим для організації медичної допомоги, є представлення даних про населення та щільність його розселення. Отримані дані наведено в табл. 1.

\section{Таблиця 1. Дані про населення та щільність} його розселення, 2001, 2011, 2018 роки

\begin{tabular}{|c|c|c|c|}
\hline Показник & 2001 & 2011 & 2018 \\
\hline $\begin{array}{l}\text { Постійне населення, } \\
\text { тис. осіб }\end{array}$ & 1258,2 & 1244,5 & 1254,0 \\
\hline Міське, $\%$ & 37,3 & 37,2 & 37,1 \\
\hline Сільське, \% & 62,7 & 62,8 & 62,9 \\
\hline Чоловіки, \% & 48,2 & 47,9 & 36,8 \\
\hline Жінки, \% & 51,8 & 52,1 & 63,2 \\
\hline $\begin{array}{l}\text { Середня очікувана } \\
\text { тривалість життя, роки }\end{array}$ & 69,00 & 70,95 & 70,99 \\
\hline Середній вік, роки & 34,8 & 36,4 & 37,3 \\
\hline
\end{tabular}

За роки дослідження (2001-2018 рр.) кількість постійного населення в області практично не змінилося $\mathrm{i}$ складає 1254,0 тис. осіб з яких 37,1\% проживає в містах та $62,9 \%$ в сільській місцевості. За вказаний період значних змін набула статева структура населення області. Частка чоловіків в структурі населення скоротилася із $48,2 \%$ до $36,8 \%$ і відповідно частка жінок збільшилася з 51,8\% до $63,2 \%$. Таким чином частка жінок в статевій структурі населення області в 1,72 разу більша ніж частка чоловіків.

Середня очікувана тривалість життя при народженні в області має тенденцію до зростання і в 2018 році становила 70,99 роки в тому числі 66,77 років у чоловіків та 75,22 років у жінок. Також зростає середній вік населення, яке проживає в області. За роки дослідження середній вік населення області зріс на 2,5 років і в 2018 році склав 37,3 роки.

Для досягнення мети дослідження була вивчена та проаналізована демографічна ситуація в області. Отримані результати наведено в табл. 2.

Якщо з 2001 по 2011 роки показник народжуваності мав тенденцію до зростання (на 27,8\%), то до 2018 року він скорочувався в став нижчим за показник 2001 року $з$ рівнем 11,0 на 1000 наявного населення. При цьому ввесь період дослідження вказаний показник в сільській місцевості був вищим ніж в мстах. При цьому необхідно зазначити, що в 2018 році сумарний коефіцієнт народжуваності склав 1,504 в розрахунку на одну жінку репродуктивного віку області. Із числа народжених дітей $23,3 \%$ в тому числі $31,8 \%$ в містах та $18,6 \%$ народжені жінками, які не перебували у зареєстрованому шлюбі. В 2018 році більше народжувалося хлопчиків ніж дівчаток. Так, на 100 народжених дівчаток було народжено 106 хлопчиків (Україна - 107).

\section{Таблиця 2. Демографічна ситуація в Закарпатській області на 1000 наявного населення, 2001, 2011, 2018 роки}

\begin{tabular}{|l|l|l|l|}
\hline \multicolumn{1}{|l|}{ Показник } & $\mathbf{2 0 0 1}$ & $\mathbf{2 0 1 1}$ & $\mathbf{2 0 1 8}$ \\
\hline $\begin{array}{l}\text { Кількість } \\
\text { живонароджень }\end{array}$ & 11,5 & 14,7 & 11,0 \\
\hline \multicolumn{1}{|l|}{ у містах } & 10,6 & 14,5 & 10,6 \\
\hline \multicolumn{1}{|l|}{ в сільській місцевості } & 12,0 & 14,8 & 11,3 \\
\hline Кількість смертей & 11,1 & 12,0 & 12,2 \\
\hline \multicolumn{1}{|l|}{ у містах } & 10,8 & 11,6 & 12,2 \\
\hline в сільській місцевості & 11,2 & 12,2 & 12,2 \\
\hline $\begin{array}{l}\text { Природній приріст, } \\
\text { скорочення (-) населення }\end{array}$ & 0,4 & 2,7 & $-1,2$ \\
\hline \multicolumn{1}{|l}{ у містах } & $-0,2$ & 2,9 & $-1,6$ \\
\hline в сільській місцевості & 0,8 & 2,6 & $-0,9$ \\
\hline
\end{tabular}

На відміну від динаміки показників народжуваності за період дослідження показники смертності населення області мали тенденцію до зростання з рівнем 12,2 на 1000 наявного населення. При цьому за всі роки дослідження вказаний показник в сільській місцевості був вищим ніж в містах, а в 2018 році він зрівнявся і склав 12,2 на 1000 наявного населення.

Показники народжуваності та смертності населення в області зумовили показники його природного руху. Якщо в 2001 та 2011 роках в області реєструвався природній приріст населення, то в 2018 році зареєстровано природній убуток (скорочення) населення на 1,2 на 1000 наявного населення. При цьому природній убуток населення зареєстровано як в містах так і в сільській місцевості. В містах він був у 1,78 разу вищим ніж в сільській місцевості.

Далі, в табл. 3 наведено дані щодо основних причин смертності населення за 2014-2018 роки.

Таблиця 3. Основні причини смертності населення Закарпатської області, 2014-2018 роки

\begin{tabular}{|l|c|c|c|c|c|}
\hline \multicolumn{1}{|c|}{ Причини } & $\mathbf{2 0 1 4}$ & $\mathbf{2 0 1 5}$ & $\mathbf{2 0 1 6}$ & $\mathbf{2 0 1 7}$ & $\mathbf{2 0 1 8}$ \\
\hline Всього померло (абс.), з них окремі причини (\%): & 14808 & 15549 & 15399 & 15077 & 15320 \\
\hline хвороби системи кровообігу & 58,62 & 59,98 & 61,14 & 62,86 & 61,69 \\
\hline новоутворення & 12,57 & 11,93 & 12,83 & 12,71 & 12,36 \\
\hline зовнішні причини смерті & 5,63 & 5,28 & 5,19 & 5,09 & 5,42 \\
\hline хвороби органів травлення & 5,40 & 5,36 & 5,21 & 5,35 & 5,71 \\
\hline хвороби органів дихання & 2,17 & 2,89 & 2,68 & 2,33 & 2,70 \\
\hline деякі інфекційні та паразитарні хвороби & 2,49 & 2,23 & 2,25 & 2,26 & 1,63 \\
\hline
\end{tabular}


Аналізуючи структуру причин смертності населення Закарпатської області необхідно відмітити, що ведучими причинами в Закарпатській області є хвороби за наступними класами: хвороби системи кровообігу, новоутворення, зовнішні причини смерті, хвороби органів травлення, хвороби органів дихання, деякі інфекційні та паразитарні хвороби. При цьому всі роки дослідження перше місце в причинах смертності населення займали хвороби системи кровообігу із збільшенням їх рівня в структурі причин смертності із 58,62\% до 61,69\%. Друге місце займали новоутворення із статистично незначущими коливаннями за роки дослідження 3 рівнем $12,36 \%$ в 2018 році. В 2014 році третє місце займали зовнішні причини смерті з рівнем 5,63\% 3 наступним уступивши третю позицію хвороби органів травлення з рівнем 5,71\% в 2018 році.

Далі вивчалися соціально-економічні чинники. В ході дослідження встановлено наступне.

Середньомісячна кількість економічно активного населення віком 15-70 років становила 558,2 тис. осіб, 3 яких 503,7 тис. були зайняті економічною діяльністю, а решта $(54,5$ тис.) - безробітні, тобто особи, які не мали роботи, але активно іiі шукали як самостійно, так і за допомогою державної служби зайнятості. Рівень зайнятості населення у віці $15-70$ років становив $54,7 \%$, а в працездатному віці - 61,6\%. Рівень безробіття серед економічно активного населення у віці 15-70 років становив 9,8\%, працездатного віку - 10,1\% (по Україні 8,6\% і 9,0\% відповідно).

Кількість зареєстрованих безробітних (за даними Закарпатського обласного центру зайнятості) на кінець грудня 2018 р. становила 4,6 тис. осіб. Допомогу по безробіттю отримували $81,5 \%$ осіб, які мали статус безробітного на кінець місяця. Із загальної кількості безробітних 64,8\% складали жінки. У грудні 2018 р. порівняно 3 листопадом спостерігалося збільшення обсягів зареєстрованого безробіття у більшості районів області, крім Великоберезнянського, Іршавського, Міжгірського, Перечинського районів та м. Ужгород.

При цьому, за даними головного управління статистики у Закарпатській області, індекс споживчих цін (інфляції) по області у грудні 2018 р. порівняно 3 листопадом 2018p. склав 101,1\%, по країні - 100,8\%, за січень-грудень 2018p. порівняно з груднем 2017 р. відповідно - $112,2 \%$ та $109,8 \%$. На споживчому ринку області у грудні 2018 р. порівняно з листопадом 2018 р. ціни на продукти харчування зросли на 2,3\%. Одяг і взуття за зазначений період подорожчали на 3,8\%.
Водночас ціни (тарифи) на житло, воду, електроенергію, газ та інші види палива зросли на 15,3\%, що пов'язано з підвищенням тарифів на водовідведення на $45,0 \%$, водопостачання - на 43,4\%, природний газ - на $22,9 \%$, утримання будинків та прибудинкових територій на 9,4\%, утримання та ремонт житла - на 8,5\%.

Ціни у сфері охорони здоров'я зросли на 17,3\%, у першу чергу через подорожчання на 20,3\% амбулаторних послуг.

Індекс споживчих цін на транспорт за 2018 p. порівняно з груднем 2017 р. склав 113,3\%, в основному за рахунок подорожчання вартості послуг автодорожнього пасажирського транспорту на $27,5 \%$, залізничного пасажирського транспорту - на 24,4\% та зростання цін на паливо і мастила на 9,4\%.

Зростання вартості послуг освіти в цілому на 14,8\% спричинено подорожчанням більш ніж на третину плати за утримання та виховання дітей у дошкільних закладах.

Перспективи подальших досліджень пов'язані 3 вивченням оцінки населенням Закарпатської області доступності медичної допомоги різних рівнів.

\section{Висновки}

Область займає територію площею 12,8 тис. км² із яких майже $80 \%$ займають гори. На території 13 адміністративних територій, 5 міст обласного значення, 11 міських, 19 селищних та 293 сільських рад області на кінець 2018 року проживало 1254 тис. осіб близько ста національностей.

В економіці основну частину займають такі види господарської діяльності як машинобудування, сількогосподарське виробництво, харчова промисловість, вироблення одягу і виробів із шкіри, лісозаготівля та переробка деревини. 37,1\% населення проживає в містах та $62,9 \%$ в сільській місцевості. Частка жінок в статевій структурі населення області в 1,72 разу більша ніж частка чоловіків. Показник народжуваності має тенденцію до зростання 3 рівнем 11,0 на 1000 наявного населення, а показник смертності населення має тенденцію до зростання з рівнем 12,2 на 1000 наявного населення.

Кількість економічно активного населення становить 558,2 тис. осіб, з яких 503,7 тис. зайняті економічною діяльністю, а решта (54,5 тис.) - безробітні.

Рекомендується геополітичні, демографічні та соціально-економічні характеристики Закарпатської області врахувати в ході реформування її системи охорони здоров'я.

\section{Література}

1. Лехан ВМ, Слабкий ГО, Шевченко МВ. Аналіз результатів реформування системи охорони здоров'я в пілотних регіонах: позитивні наслідки, проблеми та можливі шляхи їх вирішення. Україна. Здоров'я нації. 2015; спеціальний випуск(3): p. 67-86.

2. Закон України „Про державні фінансові гарантії медичного обслуговування населення” я № 2168-VIII. [Online].; 2017. Available from: http://search.ligazakon.ua/1_doc2.nsf/link1/T172168.html. 
3. Слабкий ГО, Зозуля IC, Зозуля АІ. Пріоритетний розвиток первинної медико-санітарної допомоги на засадах сімейної медицини. Сімейна медицина. 2014;(3 (53)): p. 25-27.

4. Баценко Д, Брагінський П, Бучма М. Як організувати систему надання первинної медичної допомоги на місцевому рівні. Міністерство охорони здоров’я України ПU«Впуд, editor. Київ: ТОВ «Агентство «Україна»; 2018.

5. Пархоменко ГЯ. Лікарня інтенсивної допомоги - лікарня європейського зразка. Вісн. соц. гігієни та орг. охорони здоров'я України. - 2011; 2: р. 39-41.

6. Постанова КМУ „Про затвердження Порядку реалізації державних гарантій медичного обслуговування населення за програмою медичних гарантій для первинної медичної допомоги на 2018 рік” від 25.04.2018 р. № 407. [Online]. Available from: https://www.apteka.ua/article/458646.

7. Стратегічна дорадча група з питань реформування системи охорони здоров'я в Україні. Національна стратегія реформування системи охорони здоров'я в Україні на період 2015-2020 років. [Online].; 2015. Available from: http://healthsag.org.ua/strategiya.

\section{References}

1. Lekhan VM, Slabkyi HO, Shevchenko MV. Analiz rezultativ reformuvannia systemy okhorony zdorovia v pilotnykh rehionakh: pozytyvni naslidky, problemy ta mozhlyvi shliakhy yikh vyrishennia. Ukraina. Zdorovia natsii. 2015; spetsialnyi vypusk(3): p. 67-86.

2. Zakon Ukrainy „Pro derzhavni finansovi harantii medychnoho obsluhovuvannia naselennia” ya \# 2168-VIII. [Online]; 2017. Available from: http://search.ligazakon.ua/1_doc2.nsf/link1/T172168.html.

3. Slabkyi HO, Zozulia IS, Zozulia AI. Priorytetnyi rozvytok pervynnoi medyko-sanitarnoi dopomohy na zasadakh simeinoi medytsyny. Simeina medytsyna. 2014;(3 (53)): p. 25-27.

4. Batsenko D, Brahinskyi P, Buchma M. Yak orhanizuvaty systemu nadannia pervynnoi medychnoi dopomohy na mistsevomu rivni. Ministerstvo okhorony zdorovia Ukrainy PU«Vpud, editor. Kyiv: TOV «Ahentstvo «Ukraina»; 2018.

5. Parkhomenko HIa. Likarnia intensyvnoi dopomohy - likarnia yevropeiskoho zrazka. Visn. sots. hihiieny ta orh. okhorony zdorovia Ukrainy. 2011; 2: p. 39-41.

6. Postanova KMU „Pro zatverdzhennia Poriadku realizatsii derzhavnykh harantii medychnoho obsluhovuvannia naselennia za prohramoiu medychnykh harantii dlia pervynnoi medychnoi dopomohy na 2018 rik” vid 25.04.2018 r. № 407 . [Online]. Available from: https://www.apteka.ua/article/458646.

7. Stratehichna doradcha hrupa z pytan reformuvannia systemy okhorony zdorovia v Ukraini. Natsionalna stratehiia reformuvannia systemy okhorony zdorovia v Ukraini na period 2015-2020 rokiv. [Online].; 2015. Available from: http://healthsag.org.ua/strategiya.

Дата надходження рукопису до редакції: 22.08.2019 p.

Мета роботи: дослідити геополітичні, демографічні та соціально-економічні характеристики Закарпатської області в аспекті проведення реформи системи охорони здоров'я в регіоні.

Матеріали та методи. Матеріалами дослідження стали дані державної та галузевої статистичної звітності за період 2001-2018 років. Методами дослідження були статистичний та структурно-логічного аналізу.

Результати та їх обговорення. Область займає територію площею 12,8 тис км² із яких майже $80 \%$ займають гори. На території 13 адміністративних територій, 5 міст обласного значення, 11 міських, 19 селищних та 293 сільських рад області на кінець 2018 року проживало 1254 тис. осіб близько ста національностей.

В економіці основну частину займають такі види господарської діяльності як машинобудування, сільськогосподарське виробництво, харчова промисловість, вироблення одягу і виробів із шкіри, лісозаготівля та переробка деревини. 37,1\% населення проживає в містах та 62,9\% в сільській місцевості. Частка жінок в статевій структурі населення області в 1,72 разу більша ніж частка чоловіків.

Показник народжуваності має тенденцію до зростання з рівнем 11,0 на 1000 наявного населення, а показник смертності населення має тенденцію до зростання з рівнем 12,2 на 1000 наявного населення.

Кількість економічно активного населення становить 558,2 тис. осіб, з яких 503,7 тис. зайняті економічною діяльністю, а решта (54,5 тис.) - безробітні.

Висновки. Рекомендується геополітичні, демографічні та соціально-економічні характеристики Закарпатської області врахувати в ході реформування ії системи охорони здоров'я.

Ключові слова: Закарпатська область, геополітичні, демографічні та соціально-економічні характеристики.

Цель работы: изучить геополитические, демографические и социально-экономические характеристики Закарпатской области в аспекте проведения реформы системы здравоохранения в регионе.

Материалы и методы. Материалами исследования стали данные государственной и отраслевой статистики за период 2001-2018 годов. Методами исследования были статистический и метод структурно-логического анализа. 
Результаты и их обсуждение. Область занимает территорию площадью 12,8 тыс. км² из которых почти $80 \%$ занимают горы. На территории 13 административных территорий, 5 городов областного значения, 11 городских, 19 поселковых и 293 сельских советов. В области на конец 2018 года проживало 1254 тыс. человек около ста национальностей.

В экономике основную часть занимают такие виды хозяйственной деятельности как машиностроение, сельскохозяйственное производство, пищевая промышленность, производство одежды и изделий из кожи, заготовка леса и переработка древесины. 37,1\% населения проживает в городах и $62,9 \%$ в сельской местности. Доля женщин в половой структуре населения области в 1,72 раза больше, чем доля мужчин. Показатель рождаемости имеет тенденцию к росту с уровнем 11,0 на 1000 имеющегося населения, а показатель смертности имеет тенденцию к росту с уровнем 12,2 на 1000 населения.

Количество экономически активного населения составляет 558,2 тыс. человек, из которых 503,7 тыс. заняты экономической деятельностью, а остальные (54,5 тыс.) - безработные.

Выводы. Рекомендуется учитывать геополитические, демографические и социально-экономические характеристики Закарпатской области в ходе реформирования ее системы здравоохранения.

Ключевые слова: Закарпатская область, геополитические, демографические и социально-экономические характеристики.

Goal of research: to study geopolitical, demographic and socio-economic characteristics of Transcarpathian region in the frames of health care system reform in the region.

Materials and methods. The data of the State and sectoral statistical reports for the period of the years 2001-2018 were used as the materials of research. Statistical method and the method of structural-and-logical analysis were applied in the course of research.

Results and their discussion. The region occupies an area of 12.8 thousand $\mathrm{km}^{2}$ of which almost $80 \%$ are occupied by the mountains. There are 13 administrative territories, 5 cities of regional significance, 11 city councils, 19 settlement councils and 293 village councils on the territory of the region with 1,254 thousand people of about one hundred nationalities living in the region at the end of 2018 .

Engineering, agricultural production, food industry, clothing and leather goods, timber harvesting and wood processing compose the main part of economy in the region. $37.1 \%$ of the population live in cities and $62.9 \%$ in rural areas. The proportion of women in the sexual structure of the population in the region is 1.72 time larger than the proportion of men. Fertility rates tend to rise with the level of 11.0 per 1000 existing population, and the mortality rate tends to rise with the level of 12.2 per 1000 population.

The number of economically active population is 558.2 thousand people, of which 503.7 thousand are employed in economic activities, and the rest (54.5 thousand) are unemployed.

Conclusions. It is recommended to take into account geopolitical, demographic and socio-economic characteristics of Transcarpathian region in the course of reform in health care system.

Key words: Transcarpathian region, geopolitical, demographic and socio-economic characteristics.

\section{Відомості про автора}

Данко Дана Валеріївна - кандидат педагогічних наук, доцент, доцент кафедри соціальної медицини та гігієни УжНУ; 88001, м. Ужгород, пл. Народна, 3.

+380 (50) 508-91-24, dankodana01@gmail.com. 